\title{
Anne de La Roche-Guilhem, Histoire des favorites
}

\section{Daniela Dalla Valle}

\section{(2) OpenEdition}

\section{Journals}

\section{Edizione digitale}

URL: http://journals.openedition.org/studifrancesi/27553

DOI: 10.4000/studifrancesi.27553

ISSN: 2427-5856

\section{Editore}

Rosenberg \& Sellier

\section{Edizione cartacea}

Data di pubblicazione: 31 décembre 2006

Paginazione: 599

ISSN: 0039-2944

\section{Notizia bibliografica digitale}

Daniela Dalla Valle, «Anne de La Roche-Guilhem, Histoire des favorites », Studi Francesi [Online], 150 (L I

III) | 2006, online dal 30 novembre 2015, consultato il 08 novembre 2020. URL : http://

journals.openedition.org/studifrancesi/27553; DOI : https://doi.org/10.4000/studifrancesi.27553

Questo documento è stato generato automaticamente il 8 novembre 2020 .

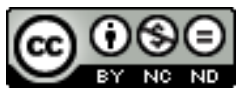

Studi Francesi è distribuita con Licenza Creative Commons Attribuzione - Non commerciale - Non opere derivate 4.0 Internazionale. 


\title{
Anne de La Roche-Guilhem, Histoire des favorites
}

\author{
Daniela Dalla Valle
}

NOTIZIA

ANNE DE LA ROCHE-GUILHEM, Histoire des favorites, éd. Els HöHNER, Saint-Etienne, Publications de l'Université de Saint-Etienne, 2005, pp. 410.

1 Edizione modernizzata della "nouvelle historique", pubblicata per la prima volta nel 1697. Un'introduzione (trenta pagine) presenta l'autrice, le sue opere e soprattutto l'opera principale, l'Histoire des favorites, non più ristampata dopo la fine del Settecento, soffermandosi anche sul problema delle fonti. Il testo è poi parcamente annotato e corredato da una breve bibliografia e da un glossario.

2 Non si può che apprezzare la pubblicazione moderna di testi narrativi importanti, da troppo tempo dimenticati. 